\title{
Physico-chemical characteristics of passion fruit flour under removal of flavedo and of maceration
}

\author{
Elaine C. O. da Silva ${ }^{1}$, Wilton P. da Silva ${ }^{1}$, Josivanda P. Gomes ${ }^{1}$, Cleide D. P. da S. e Silva ${ }^{1}$, \\ Leidjane M. de Souto $^{1} \&$ Zanelli R. T. Costa ${ }^{1}$
}

${ }^{1}$ Universidade Federal de Campina Grande/Centro de Tecnologia e Recursos Naturais/Programa de Pós-Graduação em Engenharia Agrícola. Campina Grande, PB, Brasil. E-mail: elaine-cristinna@hotmail.com - ORCID: 0000-0003-0098-9886; wiltonps@uol.com.br - ORCID: 0000-00015841-602; cleidedps@gmail.com - ORCID: 0000-0002-6504-3023; josivanda@gmail.com (Corresponding author) - ORCID: 0000-0002-2047-986X; leidjane@gmail.com - ORCID: 0000-0001-6438-4961; zanelli.tenorio@afogados.ifpe.edu.br - ORCID: 0000-0001-5719-5257

\begin{abstract}
Passion fruit has the peel (albedo and flavedo) as its major component and it can be used in the production of flour as source of nutrients and enrichment of food products. Thus, this study aimed to evaluate the production of flours from passion fruit albedo and whole peel, verifying the influences of flavedo removal and maceration, as well as the variation in drying temperature $\left(70\right.$ and $\left.80^{\circ} \mathrm{C}\right)$ on the physical and chemical characteristics of the flours. The flours has a light color with slight trend to red and stronger trend to yellow. Moisture content is within the limits established by the current norms of ANVISA (a maximum of $15 \%)$. The flavedo removal contributed to the increase of water, crude fiber, neutral detergent fiber and acid detergent fiber concentrations. However, it reduced moisture, ash, protein, lipids and carbohydrates concentrations. On the other hand, the maceration decreases luminosity, lipids and carbohydrates and increases the chromaticity $\mathrm{a}^{*}$ and $\mathrm{b}^{*}$ and moisture in the flours. In relation to the increase in temperature, a decrease was observed in the protein concentration and an increase in the concentration of ash and lipids. Based on centesimal composition, the flour should be prepared with whole peel without maceration and dried at $80^{\circ} \mathrm{C}$.
\end{abstract}

Key words: Passiflora edulis, albedo, waste management, yellow passion fruit

\section{Características físico-químicas da farinha da casca de maracujá sob remoção do flavedo e da maceração}

RESUMO: O maracujá tem a casca (albedo e flavedo) como componente majoritário, podendo esta, ser utilizada na fabricação de farinha como fonte de nutrientes e para enriquecimento de produtos alimentícios. Assim, objetivou-se neste trabalho estudar o processo de fabricação de farinha do albedo e da casca integral de maracujá nas temperaturas de 70 e $80^{\circ} \mathrm{C}$, verificando-se as influências da remoção do flavedo e da maceração nas características físicas e químicas das farinhas. As farinhas obtidas são claras, com leve disposição à tonalidade vermelha e tendência maior à coloração amarela. $\mathrm{O}$ teor de umidade encontra-se dentro dos limites estabelecidos pelas normas vigentes da ANVISA (máximo de 15\%). A remoção do flavedo contribuiu para o aumento da atividade de água e os teores de fibra bruta, fibra em detergente neutro e fibra em detergente ácido, entretanto reduziu os teores de umidade, cinzas, proteínas, lipídios e carboidratos. A maceração diminuiu a luminosidade e os teores lipídios e carboidratos e aumenta as cromaticidades $\mathrm{a}^{*} \mathrm{e} \mathrm{b}^{*}$ e a umidade nas farinhas com casca. O aumento da temperatura diminuiu o teor de proteínas e aumenta os teores de quantidade de cinzas e lipídios. Com base na composição centesimal, a farinha deve ser preparada com casca inteira sem maceração e seca a $80^{\circ} \mathrm{C}$.

Palavras-chave: Passiflora edulis, albedo, aproveitamento de resíduos, maracujá amarelo 


\section{INTRODUCTION}

Passion fruit (Passiflora edulis) is a fruit with great acceptance by populations from all over the world. Native to the Tropical America, it is rich in vitamin $\mathrm{C}$, calcium and phosphorus. Brazil has stood out as the main global producer of passion fruit for more than two decades (Meletti, 2011) and in 2016 its production was approximately 703,489 tons of passion fruit, with yield of 14,101 $\mathrm{kg} \mathrm{ha}^{-1}$ (IBGE, 2016).

Passion fruit has large amount of peel and, according to Santos et al. (2017), the components can reach $26.78 \%$ of juice, $3.59 \%$ of seeds and $69.63 \%$ of peel, which is composed of flavedo (yellow part) and albedo (white part). The albedo has in its composition a flavonoid substance known as naringin, which according to some authors can cause bitter taste in the products containing it, but can be eliminated by maceration in water. Such physical operation consists in extracting certain water-soluble substances from a product (Dias et al., 2011).

Utilization of fruit peels has been constantly studied in the elaboration of flours for preparation and nutritional enrichment of the most varied foods (Oliveira et al., 2014). Peels of pineapple, melon, orange, brazilian grapetree (Plinia cauliflora, 'jabuticaba') and passion fruit have been evaluated (Gonçalves et al., 2016; Silva et al., 2016; Araújo et al., 2017; Pádua et al., 2017).

Silva et al. (2016) obtained and characterized flour from passion fruit albedo, with drying temperatures of 50, 60, 70 and $80{ }^{\circ} \mathrm{C}$, and observed that flour samples dried at 70 and $80{ }^{\circ} \mathrm{C}$ did not differ significantly with respect to color and water activity, suggesting that more detailed studies could be conducted to obtain and characterize passion fruit whole flours arousing the interest for the research of this new product. Another important factor for the realization of the present study is the need to encourage the development of research aiming at solutions to minimize the inadequate disposal of agroindustrial wastes, which are highly substantial in the case of passion fruit processing.

Therefore, this study aimed to analyze the influence of flavedo removal and maceration in water on the production of passion fruit peel flour by evaluating its physicochemical characteristics.

\section{Material And Methods}

The analyses were carried out at the Laboratory of Storage and Processing of Agricultural Products (LAPPA) of the Federal University of Campina Grande (UFCG), Campus of Campina Grande, PB, Brazil.

Passion fruits (Passiflora edulis f. flavicarpa) from the Paraiba state, at ripe stage (completely yellow peel) were firstly washed in running water and immersed in sodium hypochlorite solution $\left(50 \mathrm{mg} \mathrm{L}^{-1}\right)$ for $5 \mathrm{~min}$, and then washed again in running water to remove the sanitizing solution.

In order to obtain eight ingredients for production of passion fruit peel flour, the passion fruits were cut in half, their pulp was removed with a spoon and $50 \%$ of their peel was cooked in pressure pan for $5 \mathrm{~min}$, to facilitate flavedo removal with aid of a spoon. The albedo and whole peels were divided into two equal parts and only one of them was subjected to the maceration step. Maceration was carried out following the method described by Dias et al. (2011), in which the material is immersed in water for $24 \mathrm{~h}$ at proportion of $400 \mathrm{~g}$ of sample for every $2 \mathrm{~L}$ of water at room temperature $\left(25 \pm 1^{\circ} \mathrm{C}\right)$. Samples were ground in a food processor (Philips Walita, Mega Master Pro RI 3173) to uniformize the size of fragments and facilitate the subsequent drying. The peels, because they were not cooked, had a more rigid surface and were thus initially sliced and then ground.

Samples of passion fruit albedo and peel, macerated and not macerated, were analyzed for moisture content, ashes, water activity (Aw) and color, based on the parameters of luminosity $\left(\mathrm{L}^{*}\right)$ and chromaticity $\left(\mathrm{a}^{*}\right.$ and $\left.\mathrm{b}^{*}\right)$. Before flour production, immediately after that, the samples were placed in polypropylene plastic bags, frozen at $-18^{\circ} \mathrm{C}$ and maintained under such condition until $24 \mathrm{~h}$ before the experiments, when they were transferred to the refrigerator to thaw.

Drying was conducted using the method described by Ferreira \& Pena (2010) with some modifications in sample mass and drying temperature, detailed below. Initially, the samples were thawed at temperature of approximately $5{ }^{\circ} \mathrm{C}$ for $24 \mathrm{~h}$ and only then subjected to drying. Drying tests were carried out in triplicate in an oven with mechanical circulation (Model 320E, Fanem, SP, Brazil), at temperatures of 70 and $80{ }^{\circ} \mathrm{C}$. A mass of approximately $800 \mathrm{~g}$ of the thawed residue was weighed on a tray, distributed in such a way to form a layer with approximately the same thickness (about $1.5 \mathrm{~cm}$ ), allowing the drying process to occur as uniform as possible. Drying was conducted until the sample had constant weight, and the times for drying at temperature of $70{ }^{\circ} \mathrm{C}$ were 1860 , 1380,1920 and $1440 \mathrm{~min}$, whereas for drying at temperature of $80^{\circ} \mathrm{C}$ were $1260,780,1260$ and $840 \mathrm{~min}$ for albedo, macerated albedo, peel and macerated peel, respectively.

After the drying processes, the eight ingredients (Table 1) were ground in a knife mill (Model TE - 650/1, Tecnal) and placed in laminated packages, which were sealed and stored in a dry place at room temperature $\left(25^{\circ} \mathrm{C}\right)$ until the analyses of characterization.

Water activity was determined through direct measurement, by placing the sample in the compartment of the water activity meter Aqualab, model 3TE (Decagon, WA, USA), at temperature of $25{ }^{\circ} \mathrm{C}$. Color parameters were determined in a MiniScan Hunter Lab XE Plus spectrophotometer (Reston, VA, USA), using the CIELAB color system. The following parameters were determined: $L^{*}$ - luminosity; $a^{*}$ - transition from green $\left(-\mathrm{a}^{*}\right)$ to red color $\left(+\mathrm{a}^{*}\right)$; and $\mathrm{b}^{*}$ - transition from blue $\left(-b^{*}\right)$ to yellow color $\left(+b^{*}\right)$. Moisture content was determined through direct drying in an oven heated to $105^{\circ} \mathrm{C}$ until constant weight, whereas ashes were determined in a

Table 1. Nomenclature adopted for the eight drying experiments involving: $70 / 80{ }^{\circ} \mathrm{C}$; with/without maceration; albedo/whole peel

\begin{tabular}{cccc} 
Peel & $\begin{array}{c}\text { Drying } \\
\text { temperature }\left({ }^{\circ} \mathrm{C}\right)\end{array}$ & $\begin{array}{c}\text { With } \\
\text { maceration }\end{array}$ & $\begin{array}{c}\text { Without } \\
\text { maceration }\end{array}$ \\
\cline { 3 - 4 } & 70 & Momenclature of the ingredients \\
Albedo & 80 & MA70 & A70 \\
Whole & 70 & MP70 & A80 \\
peel & 80 & MP80 & P70 \\
\hline
\end{tabular}


muffle furnace at $550{ }^{\circ} \mathrm{C}$ for $24 \mathrm{~h}$. Proteins were determined by Kjeldahl digestion, with conversion to protein by the factor 6.25 , and both analyses were conducted according to the norms of IAL (2008).

Lipids were determined following the method of Bligh \& Dyer (1959). Carbohydrates were determined by difference from the total of moisture, proteins, ashes, lipids and crude fiber. Pectin concentration was determined using the gravimetric method by precipitation with calcium pectate, as described by Pearson (1991). Fiber concentration was determined using the methodologies described by Silva \& Queiroz (2002).

The results were subjected to analysis of variance with means comparison by Tukey test at $\mathrm{p} \leq 0.05$ using the program Assistat 7.7 (Silva \& Azevedo, 2016).

\section{Results AND Discussion}

The physical-chemical characteristics of passion fruit albedo and peel, with and without maceration, are presented in Table 2.

Moisture content was very high in the samples, even in the sample of whole peel, which was not either cooked or macerated and, despite that, showed moisture content of 89.77\%; in addition, that was the only sample which differed statistically by Tukey test ( $\mathrm{p}<0.05)$. The macerated peel had a $4.47 \%$ increase in moisture content, possibly because of the time it remained immersed in water. Albedo samples showed higher and almost equal moisture contents, around 93\%. This increase was already expected because albedo samples were previously cooked to remove the flavedo from the peel and, during cooking, water was incorporated into the sample, which explains the increase in moisture content. The difference in the increase of moisture between macerated albedo and peel, in relation to those without maceration, demonstrates that the peel retains higher water content during maceration because albedo samples were probably already saturated by water, which caused almost no difference between the values.

Silva et al. (2017) studied the dehydration of residues (composed of peel, seed, albedo, pulp remains) from yellow passion fruit processing through different methodologies and obtained moisture of $82.88 \%$. Ferreira \& Pena (2010) found moisture content of $85.3 \%$ in a study on the drying of yellow passion fruit (juice residue). Oliveira et al. (2002) found moisture content of $89.08 \%$ studying alternative use of yellow passion fruit peel. In these studies, moisture contents were lower than those obtained in the present study and were closer to the content found in the peel, same material studied by these authors, thus demonstrating the coherence of the results.

Ash concentration in the albedo with and without maceration are higher compared to peel and macerated peel.
López-Vargas et al. (2013), in coproducts of yellow passion fruit, obtained value of $5.00 \%$, and Oliveira et al. (2002) reported a value of $0.92 \%$, which despite being the lowest among these two is almost double the value of 0.48 found in the present study for yellow passion fruit peel.

Water activity in all samples was very high and did not differ statistically by Tukey test ( $\mathrm{p} \leq 0.05)$, varying from 0.995 to 0.998 . The obtained results demonstrate that most of the water is free and can be used in chemical, enzymatic and microorganism growth reactions. Thus, the dehydration of these products is extremely important for their conservation. Araújo et al. (2017) obtained for pineapple, banana, melon and orange peels values of $0.991,0.981,0.990$ and 0.993 , respectively, which were all lower than those of the present study.

Luminosity $L^{*}$ was slightly higher in samples of albedo than in those of whole peel, showing that the presence of flavedo had little influence on this parameter, but all samples tended to a light color. The parameter $\mathrm{a}^{\star}$ revealed that the albedo sample tended to green color, whereas the others slightly tended to red color, especially the whole peel. For the parameter $b^{*}$, all samples tended to yellow color, as already expected, due to the coloring characteristics of the fruit used to obtain the raw material analyzed. In addition, samples without maceration tended more to this color than macerated samples, showing that the period of immersion in water influences this parameter.

Reolon (2008) found luminosity varying from 88.1 on the first day to 77.3 on the last day, demonstrating that the analyzed peel exhibited a lighter color in all moments. The parameter $\mathrm{a}^{*}$ varied between 2.88 and 3.25 , thus the sample tended to a reddish color during all days and only on the first day of analysis its value was close to the 2.54 found in the present study, also for yellow passion fruit peel. The parameter $b^{*}$ increased until the $6^{\text {th }}$ day of storage, followed by a reduction (initially of 16.6 , to 18.2 and to 17.2 on the last day approximately); on all days, the peel sample was less yellow than those in the present study. For all color parameters analyzed $\left(\mathrm{L}^{*}, \mathrm{a}^{*}\right.$ and $\left.\mathrm{b}^{*}\right)$ the samples differed statistically by Tukey test at 0.05 probability level.

The water activity and color means of the flours produced with passion fruit peel and albedo with and without maceration after drying at 70 and $80^{\circ} \mathrm{C}$ are shown in Table 3.

Water activity was higher in flours produced with ingredients that were not macerated than in those subjected to maceration, demonstrating that raw material maceration contributed to greater loss of free water after drying. However, although the flours that had undergone the maceration process showed lower Aw, the samples processed without this process also showed Aw lower than 0.3 , which guarantees safety from a microbiological and also chemical and biochemical points

Table 2. Characterization of albedo and whole peel of yellow passion fruit with and without maceration

\begin{tabular}{|c|c|c|c|c|}
\hline \multirow{2}{*}{ Variables } & \multicolumn{4}{|c|}{ Mean \pm Standard deviation } \\
\hline & Albedo & Macerated albedo & Peel & Macerated peel \\
\hline Moisture (\%) & $93.55 a \pm 0.360$ & $93.39 a \pm 0.650$ & $89.77 b \pm 0.170$ & $94.24 \mathrm{a} \pm 0.070$ \\
\hline Ashes (\%) & $0.54 \mathrm{a} \pm 0.050$ & $0.52 a \pm 0.040$ & $0.49 b \pm 0.120$ & $0.45 b \pm 0.010$ \\
\hline Aw & $0.995 a \pm 0.001$ & $0.998 a \pm 0.002$ & $0.996 a \pm 0.001$ & $0.997 \mathrm{a} \pm 0.001$ \\
\hline$L^{*}$ & $56.19 b \pm 0.290$ & $58.76 a \pm 0.190$ & $54.42 c \pm 0.250$ & $53.42 d \pm 0.140$ \\
\hline$a^{*}$ & $-3.12 d \pm 0.110$ & $0.57 b \pm 0.030$ & $2.51 \mathrm{a} \pm 0.110$ & $1.19 c \pm 0.010$ \\
\hline$b^{\star}$ & $20.55 b \pm 0.410$ & $13.24 d \pm 0.220$ & $30.44 a \pm 0.450$ & $19.59 c \pm 0.240$ \\
\hline
\end{tabular}


Table 3. Water activity and color of the flours prepared with albedo and whole peel of yellow passion fruit with and without maceration, dried at temperatures of 70 and $80^{\circ} \mathrm{C}$

\begin{tabular}{|c|c|c|c|c|}
\hline \multirow{3}{*}{$\begin{array}{l}\text { Passion fruit } \\
\text { flours }^{1}\end{array}$} & \multicolumn{4}{|c|}{ Mean \pm standard deviation } \\
\hline & \multicolumn{4}{|c|}{ Parameters } \\
\hline & $\overline{A W}$ & $L^{*}$ & $a^{*}$ & $\overline{b^{*}}$ \\
\hline A70 & $0.285 a b \pm 0.02$ & $48.76 \mathrm{~g} \pm 0.11$ & $10.91 \mathrm{a} \pm 0.08$ & $27.53 c \pm 0.15$ \\
\hline MA70 & $0.213 \mathrm{~cd} \pm 0.01$ & $64.12 b \pm 0.12$ & $4.89 \mathrm{~g} \pm 0.02$ & $22.55 h \pm 0.21$ \\
\hline P70 & $0.237 a b c d \pm 0.03$ & $52.39 \mathrm{c} \pm 0.07$ & $8.94 \mathrm{e} \pm 0.03$ & $26.25 d \pm 0.19$ \\
\hline MP70 & $0.184 d \pm 0.02$ & $52.12 d \pm 0.07$ & $10.06 c \pm 0.04$ & $29.41 \mathrm{a} \pm 0.16$ \\
\hline A80 & $0.292 \mathrm{a} \pm 0.02$ & $48.49 h \pm 0.12$ & $10.49 b \pm 0.03$ & $24.30 f \pm 0.23$ \\
\hline MA80 & $0.225 \mathrm{~cd} \pm 0.01$ & $66.38 \mathrm{a} \pm 0.24$ & $4.31 \mathrm{~h} \pm 0.15$ & $23.13 \mathrm{~g} \pm 0.39$ \\
\hline P80 & $0.250 a b c \pm 0.03$ & $49.86 f \pm 0.15$ & $8.55 f \pm 0.05$ & $25.19 \mathrm{e} \pm 0.25$ \\
\hline MP80 & $0.227 b c d \pm 0.02$ & $51.18 \mathrm{e} \pm 0.06$ & $9.56 d \pm 0.04$ & $28.84 b \pm 0.14$ \\
\hline
\end{tabular}

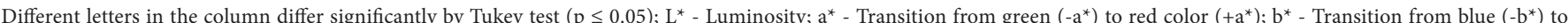
yellow color $\left(+b^{*}\right) ; 1-$ For description of passion fruit flours, see Table 1

of view, due to the content of free water, which reduces the speed of reactions of this nature. The same can be observed in relation to the type of sample; samples composed of whole peel had lower water activity than those composed of albedo.

Silva et al. (2016) found water activity values of $0.535,0.362$, 0.266 and 0.245 in flours prepared with macerated albedo of yellow passion fruit dehydrated at temperatures of 50, 60, 70 and $80^{\circ} \mathrm{C}$, respectively. The values obtained at 70 and $80^{\circ} \mathrm{C}$ were higher than those of the present study, 0.213 for MA70 and 0.225 for MA80, possibly because these authors did not grind the albedo before drying, causing higher amount of water to be retained.

In relation to water activity of flours produced without the maceration step, Oliveira et al. (2016) analyzed physicochemical, technological and morphological properties of flour produced with passion fruit peel and found values of 0.398 and 0.415 , relative to two different lots of flour, both dried at $60{ }^{\circ} \mathrm{C}$. Cazarin et al. (2014), analyzing the antioxidant capacity and chemical composition of passion fruit peel, found value of 0.43 in the peel flour dried at $50{ }^{\circ} \mathrm{C}$ until a moisture content lower than $10 \%$. Deus et al. (2014) observed values of 0.52 , 0.38 and 0.29 with drying at 30,45 and $60{ }^{\circ} \mathrm{C}$, respectively. All these authors obtained higher values of water activity, which indicates that the flours in the present study, without exception, are more effective for conservation for longer time with no damage caused by microbiological or enzymatic reactions resulting from the content of free water available.

All flours can be considered as light-colored, with slight trend to red and stronger trend to yellow. All flours differed in all color parameters analyzed. In relation to the increase in temperature, it was observed that it caused a slight reduction in the parameters of brightness, $\mathrm{a}^{*}$ chromaticity and $\mathrm{b}^{\star}$ chromaticity of the samples. Regarding luminosity $\left(L^{*}\right)$, samples composed of whole peel are lighter than those containing only the albedo, but the maceration process caused luminosity in the samples containing albedo to be considerably higher. Silva et al. (2016) found very high values of luminosity $(83.99,94.30,94.50$ and 89.77$)$ in samples of flours made with macerated albedo and dried at temperatures of 50, 60, 70 and $80^{\circ} \mathrm{C}$. Conversely, Oliveira et al. (2016) observed lower values in their experiments (41.45 and 40.46), relative to two different lots of flour made with passion fruit peel.

For chromaticity $\mathrm{a}^{\star}$, there was a slight trend to red color, with a little more intensity in samples dried at $70^{\circ} \mathrm{C}$. In relation to the maceration process, the trend was considerably smaller in samples prepared with macerated albedo than in those not macerated, whereas the sample of macerated peel showed slight increase in comparison to that without maceration. Silva et al. (2016) obtained values of 1.82, 3.18, 3.63 and 4.62, after drying at $50,60,70$ and $80{ }^{\circ} \mathrm{C}$. Oliveira et al. (2016) obtained $\mathrm{a}^{*}$ of 3.60 and 3.78, both higher than those found in the present study.

Values of chromaticity $b^{*}$ revealed that the samples of macerated albedo had lower trend to the yellow color than the others, whereas macerated peels obtained higher values, which demonstrates the influence of flavedo on this parameter. Silva et al. (2016) obtained $b^{*}$ values of 20.09, 26.28, 26.76 and 30.05 after drying at temperatures of $50,60,70$ and $80{ }^{\circ} \mathrm{C}$, respectively, which are similar to but higher than the values 22.55 and 23.13 obtained for the same sample with the same drying temperatures used in the present study. On the other hand, Oliveira et al. (2016) found lower values, 16.69 and 15.88, for two different lots of flour dried at $60{ }^{\circ} \mathrm{C}$.

Furthermore, it was observed that sample color was influenced by the increase in drying temperature, which contributed to the reduction of all parameters $\left(\mathrm{L}^{*}, \mathrm{a}^{*}\right.$ and $\left.\mathrm{b}^{*}\right)$, except for the sample of macerated albedo with respect to luminosity $\mathrm{L}^{\star}$ and chromaticity $\mathrm{b}^{\star}$.

The centesimal composition of the flours is presented in Table 4.

Moisture content in the analyzed flours is within the limits established by the Brazilian Health Regulatory Agency (ANVISA), which stipulates maximum moisture of $15 \%\left(\mathrm{~m} \mathrm{~m}^{-1}\right)$ for flours (Brasil, 2005).

The moisture content of the samples did not differ statistically by Tukey test ( $p \leq 0.05)$. Thus, it is believed that after drying there was no influence of maceration and drying temperature on moisture content. Regarding the drying temperature used, it was observed that the increment of temperature increased lost moisture content in samples of macerated albedo and samples of peel. Therefore, it is not possible to distinguish the influence of the maceration process and increase of drying temperature on the moisture content of the flours produced.

Some authors have observed higher moisture contents in flours produced from passion fruit peel, namely: Oliveira et al. (2016) in two different lots and Oliveira et al. (2015), who studied pectin extraction from passion fruit peel using moderate electric field methods and conventional heating extraction methods, both after drying at $60^{\circ} \mathrm{C}$ for $72 \mathrm{~h}$; Cazarin et al. (2014) at $50{ }^{\circ} \mathrm{C}$ and Ferreira \& Pena (2010) at 60, 70 and 
Table 4. Centesimal composition of flours made with albedo and whole peel of yellow passion fruit with and without maceration, dried at temperatures of 70 and $80^{\circ} \mathrm{C}$

\begin{tabular}{|c|c|c|c|c|c|}
\hline \multirow{3}{*}{ Samples } & \multicolumn{5}{|c|}{ Mean \pm Standard deviation } \\
\hline & \multicolumn{5}{|c|}{$(\%)$} \\
\hline & Moisture & Ashes & Proteins & Lipids & Carbohydrates \\
\hline A70 & $5.13 \mathrm{a} \pm 0.08$ & $7.31 \mathrm{a} \pm 0.42$ & $7.81 \mathrm{a} \pm 0.43$ & $0.08 b c \pm 0.010$ & $48.73 a b \pm 0.70$ \\
\hline MA70 & $2.84 \mathrm{a} \pm 0.16$ & $4.98 b c \pm 0.47$ & $3.22 b \pm 0.39$ & $0.06 c \pm 0.010$ & $32.63 c \pm 0.33$ \\
\hline P70 & $3.17 \mathrm{a} \pm 0.34$ & $6.87 a \pm 0.18$ & $1.04 c \pm 0.30$ & $0.12 a b c \pm 0.020$ & $51.24 a \pm 0.41$ \\
\hline MP70 & $4.36 a \pm 0.12$ & $6.65 a b \pm 0.83$ & $3.47 b \pm 0.74$ & $0.12 a b c \pm 0.010$ & $49.24 a b \pm 0.63$ \\
\hline A80 & $4.63 a \pm 0.24$ & $7.65 a \pm 0.06$ & $3.78 b \pm 0.55$ & $0.15 a \pm 0.030$ & $48.17 a b \pm 1.24$ \\
\hline MA80 & $3.00 a \pm 0.08$ & $5.02 b c \pm 0.23$ & $1.14 \mathrm{c} \pm 0.61$ & $0.07 b c \pm 0.001$ & $36.34 c \pm 1.10$ \\
\hline P80 & $3.62 \mathrm{a} \pm 0.08$ & $7.01 \mathrm{a} \pm 0.11$ & $3.77 b \pm 0.55$ & $0.13 a b \pm 0.060$ & $44.93 b \pm 1.74$ \\
\hline MP80 & $4.28 a \pm 0.09$ & $7.15 a \pm 0.24$ & $1.16 c \pm 0.50$ & $0.11 a b c \pm 0.010$ & $48.42 a b \pm 1.72$ \\
\hline
\end{tabular}

Different letters in the same column differ significantly by Tukey test $(\mathrm{p} \leq 0.05)$

$80{ }^{\circ} \mathrm{C}$. In the four studies cited above, the values of $6.72,4.75$, $6.61,9.48,5.9,6.0$ and 5.9 , respectively, were obtained. Silva et al. (2016), analyzing flour made from macerated albedo dried at $70{ }^{\circ} \mathrm{C}$, obtained value of 3.53 , higher than the 2.84 obtained in the present study for the same flour. Thus, it can be noted that the maceration process in combination with the temperatures used in the drying contributed to a reduced moisture content.

Ash contents in the flour samples varied from 4.98 in the sample MA70 to 7.65 in the sample A80. Maceration contributed to the reduction in the amount of ashes, since all macerated samples had lower amount than those not subjected to maceration, and temperature increment caused increase in ash content, proportional to the removal of water. Thus, samples without maceration and dried at higher temperature have higher ash contents, which is important because it indicates higher contents of minerals, enriching the final product. Oliveira et al. (2016) found a value close to that of the present study, 7.24 , in flour made from passion fruit peel after drying at $60{ }^{\circ} \mathrm{C}$. Cazarin et al. (2014) dried at $50{ }^{\circ} \mathrm{C}$ and obtained 6.88, which is almost identical to that of the peel dried at $70{ }^{\circ} \mathrm{C}$ in the present study. On the other hand, Oliveira et al. (2015) observed higher value, 9.27, and Silva et al. (2016) found a lower value, 1.95 , studying flour made with macerated albedo dried at $70{ }^{\circ} \mathrm{C}$.

The maceration process caused a considerable reduction in protein concentration, which can be explained by the solubility of proteins in water. Only the sample P70 had lower content, increasing from 1.04 (without maceration) to 3.47 (PM70). With the exception of the flour made with the whole peel and without maceration there was degradation of the proteins as the drying temperature increased from 70 to $80^{\circ} \mathrm{C}$. The sample of flour made with albedo had a considerably higher content than the others, a value which was close to those obtained by Oliveira et al. (2016) in the two lots studied, after drying at 60 ${ }^{\circ} \mathrm{C}$. Oliveira et al. (2015) also dried at $60^{\circ} \mathrm{C}$ and obtained $4.9 \%$, whereas Cazarin et al. (2014) obtained 3.94\% after drying at $50{ }^{\circ} \mathrm{C}$, and Ferreira \& Pena (2010) obtained value of $6.0 \%$ for drying at temperatures of 60,70 and $80^{\circ} \mathrm{C}$. All the values found refer to the flour produced with yellow passion fruit peel and are higher than those obtained in the present study, which used higher temperature and maceration in some cases. Samples of macerated albedo and macerated peel did not differ statistically by Tukey test for both temperatures, when considering the same drying temperature.

For lipids, in all cases the flours had very low value, below $1.0 \%$, indicating that the flours have low capacity to provide energy. In addition, it was observed that three of the flours dried at $70{ }^{\circ} \mathrm{C}$ (A, MA and $\mathrm{P}$ ) had an even lower value than those dried at $80{ }^{\circ} \mathrm{C}$ and that the maceration process also interfered with the reduction in this value, except for flours obtained from peels dried at $70^{\circ} \mathrm{C}$, without no alteration. The flours in the present study were shown to have lower lipid concentration than those analyzed by other authors, both in flours made with passion fruit peel by Oliveira et al. (2016) in two different lots and Oliveira et al. (2015) after drying at $60^{\circ} \mathrm{C}$, Cazarin et al. (2014) after drying at $50{ }^{\circ} \mathrm{C}$, and in flour made with macerated albedo of passion fruit by Silva et al. (2016) after drying at $70{ }^{\circ} \mathrm{C}$, since they found values of $1.16,0.98,2.08$, 0.31 and $0.63 \%$, respectively. According to the Tukey test, the greatest difference in lipid concentration was found between the samples MA70, 0.06\% and the sample A80, 0.15\%.

Concentrations of carbohydrates varied from 32.63 in the sample MA70 to 51.24 in the sample P70. The maceration process generally reduced carbohydrate content of flours, such degradation being correlated, by food biochemistry, with variations in color parameters, which also reduced with this increase. Based on the Tukey test, only the sample of peel without maceration differed statistically as temperature increased; with respect to the maceration process, samples of peels with and without maceration were statistically equal. Oliveira et al. (2016) found values of 3.14 and $15.17 \%$, after drying two lots of flour at $60{ }^{\circ} \mathrm{C}$, whereas Ferreira \& Pena (2010) found value of $21.1 \%$ after drying at 60,70 and $80{ }^{\circ} \mathrm{C}$, both studies using flours made with whole peel of passion fruit. These results are much lower than the ones found in the present study, and the contents found in samples of macerated albedo were the closest ones, but still very different: 32.63 and $36.34 \%$ after drying at 70 and $80{ }^{\circ} \mathrm{C}$, respectively.

The means of pectin, crude fiber, neutral detergent fiber (NDF) and acid detergent fiber (ADF) are presented in Table 5.

Pectin concentrations were extremely low in the flours, indicating that the flour does not have the capacity to form gels, unlike the the fresh peel of passion fruit. Oliveira et al. (2016) found pectin concentrations of 6.98 and $13.54 \%$ in both lots of flours studied, after drying passion fruit peels at $60{ }^{\circ} \mathrm{C}$. Probably, the high drying temperatures contributed to the reduction in pectin concentrations. According to the Tukey test, the flours MP70 and A80 were the only ones which differed from the others. It should be noted that there was no uniformity in the results that showed increase or reduction of the pectin content caused by the influence of maceration or flavedo removal. 
Table 5. Contents of pectin, crude fiber, neutral detergent fiber (NDF) and acid detergent fiber (ADF) contents of flours made with albedo and whole peel of yellow passion fruit with and without maceration, dried at temperatures of 70 and $80{ }^{\circ} \mathrm{C}$

\begin{tabular}{|c|c|c|c|c|}
\hline \multirow{3}{*}{ Samples } & \multicolumn{4}{|c|}{ Mean \pm standard deviation } \\
\hline & \multicolumn{4}{|c|}{$(\%)$} \\
\hline & Pectin & Crude fiber & NDF & ADF \\
\hline A70 & $0.29 a b \pm 0.16$ & $30.94 d \pm 0.15$ & $45.77 c \pm 0.17$ & $33.47 b \pm 0.23$ \\
\hline MA70 & $0.06 b c \pm 0.04$ & $56.27 \mathrm{a} \pm 0.20$ & $68.33 a b \pm 2.36$ & $52.17 \mathrm{a} \pm 2.24$ \\
\hline P70 & $0.06 b c \pm 0.03$ & $37.56 \mathrm{bcd} \pm 0.61$ & $52.32 c \pm 0.46$ & $34.32 b \pm 1.19$ \\
\hline MP70 & $0.45 a \pm 0.14$ & $36.16 \mathrm{bcd} \pm 0.35$ & $49.08 c \pm 0.59$ & $34.06 b \pm 0.09$ \\
\hline A80 & $0.04 \mathrm{c} \pm 0.04$ & $35.62 \mathrm{~cd} \pm 1.29$ & $46.44 \mathrm{c} \pm 0.70$ & $35.61 b \pm 0.36$ \\
\hline MA80 & $0.09 b c \pm 0.06$ & $54.43 \mathrm{a} \pm 1.26$ & $70.31 \mathrm{a} \pm 1.02$ & $53.26 a \pm 0.28$ \\
\hline P80 & $0.10 b c \pm 0.06$ & $40.54 b \pm 2.25$ & $61.88 b \pm 1.25$ & $35.72 b \pm 0.85$ \\
\hline MP80 & $0.06 b c \pm 0.06$ & $38.88 b c \pm 1.25$ & $51.94 \mathrm{c} \pm 1.50$ & $36.19 b \pm 0.26$ \\
\hline
\end{tabular}

Different letters in the same column differ significantly by Tukey test $(\mathrm{p} \leq 0.05)$

Regarding the amount of crude fiber in the samples, the flours made with macerated albedo dried at both temperatures stood out with more than $50 \%$ of this component, which can be explained by the fact that maceration has concentrated the solid constituents of the albedo samples. In general, the maceration process contributed to the reduction of crude fiber only in the sample of peel dried at $80^{\circ} \mathrm{C}$, whereas the increase in drying temperature reduced crude fiber content in the sample of macerated albedo. Silva et al. (2016) found crude fiber content of $58.8 \%$ in the flour of macerated albedo dried at $70{ }^{\circ} \mathrm{C}$, a value very close to that found in the present study for the same product, demonstrating the coherence of the result. Deus et al. (2014) obtained values of 64.7, 65.6 and $64.9 \%$ in the flours produced with passion fruit peel after drying at 30,45 and $60{ }^{\circ} \mathrm{C}$, respectively. The values of all flours (Table 5 ) were lower than those presented in both studies. According to the Tukey test, flours composed of peels did not differ with the maceration process; however, with increasing temperature, it can be considered that all flours are statistically similar at 0.05 probability level.

The contents of neutral detergent fiber (NDF), which represents the components cellulose, hemicellulose and lignin in the samples, important for the diet, were higher than $45.77 \%$ (A70). The maceration process contributed to the increase in NDF in the samples of albedo and to its reduction in samples of whole peel. The increment of temperature caused increase of NDF in all samples. According to the Tukey test, the sample of peel differed with the increase of temperature and only the sample of peel dried at $70^{\circ} \mathrm{C}$ did not differ with the maceration process. Souza et al. (2008) found NDF concentration of 51.73. This value is very close to the ones found in the present study in flours made with macerated peel dried at $80^{\circ} \mathrm{C}$ and peel dried at $70^{\circ} \mathrm{C}$.

In relation to the acid detergent fiber (ADF), which represents cellulose and lignin, it was observed that both maceration and increment of drying temperature contributed to the higher results. Samples of macerated albedo were the only ones which differed by Tukey test. Souza et al. (2008) found $\mathrm{ADF}$ content of $41.67 \%$ in the sample of commercial flour, only lower than those of samples of macerated albedo analyzed in the present study, equal to 52.17 and $53.26 \%$ after drying at 70 and $80^{\circ} \mathrm{C}$, respectively.

\section{Conclusions}

1. Maceration contributed to the production of flours with reduced water activity, concentrations of lipids and, in some samples, moisture, ashes, proteins, carbohydrates and neutral detergent fiber (NDF); however, it increased luminosity $\left(\mathrm{L}^{*}\right)$, besides the color parameters $\mathrm{a}^{\star}$ and $\mathrm{b}^{*}$, crude fiber and acid detergent fiber (ADF).

2. Increase in drying temperature reduced the color parameters $L^{*}, a^{*}, b^{*}$, carbohydrates and increased water activity, ashes, most of the contents of lipids, proteins, crude fiber, NDF and ADF concentrations.

3. Pectin contents were low in all flours.

4. Flour made with whole peel of passion fruit without maceration and dried at $80{ }^{\circ} \mathrm{C}$ is recommended as the best alternative based on the centesimal composition.

5. The recommended temperature for peel drying is $80^{\circ} \mathrm{C}$.

\section{Literature Cited}

Araújo, K. T. A.; Silva, R. M.; Silva, R. C.; Figueirêdo, R. M. F. de; Queiroz, A. J. de M. Caracterização físico-química de farinhas de frutas tropicais. Revista Brasileira de Agrotecnologia, v.7, p.110-115, 2017.

Bligh, E. G.; Dyer, W. J. A lipid method of total lipid extraction and purification. Canadian Journal of Biochemistry, v.37, p.911-917, 1959. https://doi.org/10.1139/y59-099

Brasil. Resolução RDC n 263, 22 de setembro de 2005. Aprova o "Regulamento técnico para produtos de cereais, amidos, farinhas e farelos". Órgão emissor: ANVISA - Agência Nacional de Vigilância Sanitária Available on: <http://bvsms.saude.gov.br/bvs/saudelegis/ anvisa/2005/rdc0263_22_09_2005.html >. Access on Jun. 2019.

Cazarin, C. B. B.; Silva, J. K.; Colomeu, T. C.; Zollner, R. L.; Maróstica Júnior, M. R. Capacidade antioxidante e composição química da casca de maracujá (Passiflora edulis). Ciência Rural, v.44, p.16991704, 2014. https://doi.org/10.1590/0103-8478cr20131437

Deus, G. I.; Silva, M. S.; Souza, A. R. M.; Santiago, R. A. C.; Lu, D. L. Efeitos da temperatura de secagem nos teores de compostos cianogênicos totais da casca de maracujá. Alimentação Humana, v.20, p.2-3, 2014.

Dias, M. V.; Figueiredo, L. P.; Valente, W. A.; Ferrua, F. Q.; Pereira, P. A. P.; Pereira, A. G. T.; Borges, S. V.; Clemente, P. R. Estudo de variáveis de processamento para produção de doce em massa da casca do maracujá (Passiflora edulis f. flavicarpa). Ciência e Tecnologia de Alimentos, v.31, p.65-71, 2011. https://doi. org/10.1590/S0101-20612011000100008

Ferreira, M. F. P.; Pena, R. S. Estudo da secagem da casca do maracujá amarelo. Revista Brasileira de Produtos Agroindustriais, v.12, p.15-28, 2010. https://doi.org/10.15871/1517-8595/rbpa. v12n1p15-28 
Gonçalves, J. Q.; Silva, M. A. P.; Plácido, G. R.; Caliari, M.; Silva, R. M.; Moura, L. C.; Souza, D. G. Secagem da casca e polpa da banana verde (Musa acuminata): Propriedades físicas e funcionais da farinha. Global Science Technology, v.9, p.62-72, 2016.

IAL - Instituto Adolfo Lutz. Métodos físico-químicos para análise de alimentos. 1.ed. digital. São Paulo: Instituto Adolfo Lutz, 2008. $1020 \mathrm{p}$

IBGE - Instituto Brasileiro de Geografia e Estatística. Culturas temporárias e permanentes 2016. Produção agrícola municipal. Rio de Janeiro: IBGE, 2016. 64p.

López-Vargas, J. H.; Fernández-López, J.; Pérez-Álvarez, J. A.; Viuda-Martos, M. Chemical, physico-chemical, technological, antibacterial and antioxidante properties of dietary fiber powder obtained from yellow passion fruit (Passiflora edulis var. Flavicarpa) co-products. Food Research International, v.51, p.756-763, 2013. https://doi.org/10.1016/j.foodres.2013.01.055

Meletti, L. M. M. Avanços na cultura do maracujá no Brasil. Revista Brasileira de Fruticultura, v.33, p.83-91, 2011. https://doi. org/10.1590/S0100-29452011000500012

Oliveira, C. F.; Giordani, D.; Gurak, P. D.; Cladera-Oliveira, F.; Marczak, L. D. F. Extraction of pectin from passion fruit peel using moderate electric field and conventional heating extraction methods. Innovative Food Science \& Emerging Technologies, v.29, p.201-208, 2015. https://doi.org/10.1016/j.ifset.2015.02.005

Oliveira, C. F.; Gurak, P. D.; Cladera-Olivera, F.; Marczak, L. D. F. Evaluation of physico-chemical, technological and morphological characteristics of powdered yellow passion fruit peel. International Food Research Journal, v.23, p.1653-1662, 2016.

Oliveira, G. S.; Costa, J. M. C.; Afonsi, M. R. A. A. Caracterização e comportamento higroscópico do pó da polpa de cajá liofilizada. Revista Brasileira de Engenharia Agrícola e Ambiental, v.18, p.1059-1064, 2014. https://doi.org/10.1590/1807-1929/agriambi.v18n10p1059-1064

Oliveira, L. F.; Nascimento, M. R. F.; Borges, S. V.; Ribeiro, P. C. N.; Ruback, V. R. Aproveitamento alternativo da casca do maracujáamarelo (Passiflora edulis f. flavicarpa) para produção de doce em calda. Ciência e Tecnologia de Alimentos, v.22, p.259-262, 2002. https://doi.org/10.1590/S0101-20612002000300011
Pádua, H. C.; Silva, M. A. P.; Souza, D. G.; Moura, L. C.; Plácido, G. R.; Couto, G. V. L.; Caliaro, M. Iogurte sabor banana (Musa $A A B$, subgrupo Prata) enriquecido com farinha da casca de jabuticaba (Myrciaria jabuticaba (Vell.) Berg.). Global Science and Technology, v.10, p.89-104, 2017.

Pearson, D. The chemical analysis of foods. London: Churchill Livingston Publishr, 1991. 575p.

Reolon, C. A. Fatores de influência nas características físicoquímicas e minerais da casca do maracujá e seu aproveitamento na elaboração de doce. Marechal Cândido Rondon: Universidade Estadual do Oeste do Paraná, 2008. 84p. Dissertação Mestrado Santos, V. A.; Ramos, J. D.; Laredo, R. R.; Silva, F. O. R.; Chagas, E. A.; Pasqual, M. Produção e qualidade de frutos de maracujazeiro-amarelo provenientes do cultivo com mudas em diferentes idades. Revista de Ciências Agroveterinárias, v. 16, n. 1, p.33-40, 2017. https://doi.org/10.5965/223811711612017033 Silva, D. J.; Queiroz, A. C. Análise de alimentos: Métodos químicos e biológicos. Viçosa: UFV, 2002. 235p.

Silva, E. C. O.; Silva, W. P. da; Silva, E. T.; Lopes, J. D.; Gusmão, R. P. Obtenção e caracterização da farinha do albedo de maracujá (Passiflora edulis f. flavicarpa) para uso alimentício. Revista Verde de Agroecologia e Desenvolvimento Sustentável, v.11, p.69-74, 2016. https://doi.org/10.18378/rvads.v11i3.4062

Silva, F. de A. S. e; Azevedo, C. A. V. de. The Assistat software Version 7.7 and its use in the analysis of experimental data. African Journal of Agricultural Research, v.11, p.3733-3740, 2016. https://doi.org/10.5897/AJAR2016.11522

Silva, N. C.; Santana, R. C.; Duarte, C. R.; Barrozo, M. A. S. Impact of freeze-drying on bioactive compounds of yellow passion fruit residues. Journal of Food Process Engineering, v.40, p.1-9, 2017. https://doi.org/10.1111/jfpe.12514

Souza, M. W. S.; Ferreira, T. B. O.; Vieira, I. F. R. Composição centesimal e propriedades funcionais tecnológicas da farinha da casca do maracujá. Alimentos e Nutrição, v.19, p.33-36, 2008 . 